\title{
A Multi-Country Trade and Tourism with Endogenous Capital and Knowledge
}

\author{
Wei-Bin Zhang
}

Ritsumeikan Asia Pacific University, Japan

\section{Abstract}

Background: The study models a dynamic interaction among economic growth, structural change, knowledge accumulation, international trade and tourist flows. Objective: The purpose of this study is to introduce endogenous knowledge into a multi-country growth model with trade and tourism proposed by Zhang. The study models a dynamic interaction among economic growth, structural change, knowledge accumulation, international trade and tourist flows. Methods/Approach: The model is based on Arrow's learning by doing, the Solow one-sector growth model, the Oniki-Uzawa neoclassical trade model, and the Uzawa two-sector growth model. We first build the multi-country neoclassical growth model of endogenous knowledge with international tourism. Then we show that we can follow the motion of the $J$ country world economy with $J+1$ differential equations. Results: We simulate the motion of the three-country global economy. We carry out a comparative dynamic analysis by simulation with regard to the knowledge utilization efficiency, the efficiency of learning by doing, the propensity to save, the propensity to tour other countries, and the population. Conclusions: The global economy has a unique equilibrium.

Keywords: trade pattern, tourism, knowledge accumulation, wealth accumulation, income and wealth distribution

JEL classification: F1 1

Paper type: Research article

Received: Feb 28, 2016

Accepted: Jul 19, 2016

Citation: Zhang, W.B. (2017), "A Multi-Country Trade and Tourism with Endogenous Capital and Knowledge", Business Systems Research, Vol. 8, No. 1, pp. 71-91.

DOI: 10.1515/bsrj-2017-0007

Acknowledgments: The author is thankful to the important and suggestive comments from the two anonymous referees. The author also thanks Japan Society for the Promotion of Science for the financial support from the Grants-in-Aid for Scientific Research (C), Project No. 25380246

\section{Introduction}

The purpose of this study is to introduce endogenous knowledge into a multicountry growth model with trade and tourism proposed by Zhang (2015). The study models a dynamic interaction among economic growth, structural change, knowledge accumulation, international trade and tourist flows. Our goal is to integrate the basic economic growth mechanisms in the capital-based neoclassical growth 
theory and knowledge-based contemporary growth theory. As far as the neoclassical growth theory is concerned, our model is built on the basis of the Solow growth model, the Uzawa two-sector model, the Oniki-Uzawa trade model. Our approach to technological change is based on Arrow's learning-by-doing. Arrow (1962) first introduces endogenous technical progress by emphasizing learning-by-doing. Uzawa (1965) introduces education as a source of knowledge accumulation. The education sector is specified in creating knowledge. This sector utilizes labor and the existing stock of knowledge to produce new knowledge. The Productivity of the production sector with be enhanced with new knowledge. Many other sources of knowledge accumulation are introduced in the literature of economic growth. But on the whole theoretical research on endogenous growth and knowledge had been relatively silent from the end of the 70s till the publication of the early 1980s. There has been a new interest in theoretical research on endogenous knowledge and economic growth since the mid-1980s (Romer, 1986; Lucas, 1988; Grossman et al., 1991; Aghion et al., 1992). Since then different problems about innovation, diffusion of technology and management have been examined in the literature. Many studies show that productivity differences between countries explain much of the variation in incomes across countries, and the key determinant in productivity is technology (Manasse et al., 2001; Agénor, 2004; Aghion et al. 2009; Gersbach et al. 2013). International technology diffusion plays an important role in the pattern of worldwide technical change. In order to explain global economic growth and technological change, we consider knowledge as an international public good. In our approach all countries can access knowledge. One country utilizes knowledge without affecting any other country. This approach is different from most of recently developed trade models with endogenous knowledge (e.g. Chari et al., 1991; Martin et al., 2001; Brecher et al. 2002; Nocco, 2005; Hinloopen et al., 2013). Most studies of the recent theoretical literature models trade patterns with endogenous technological change and monopolistic competition. These studies don't take treat capital and knowledge in a consistent framework. This paper deals with interactions between endogenous wealth accumulation, knowledge creations and utilization, trade, and tourism within a compact analytical framework.

Only a few formal economic theories properly address inequalities in income and wealth among nations with microeconomic foundation. This study explains inequalities among nations with endogenous wealth accumulation and knowledge dynamics. As far as modelling production and trade patterns is concerned, we follow the neoclassical growth trade model, particularly the Oniki-Uzawa model. A dynamic model with endogenous capital accumulation and capital movements was initially developed by Oniki and Uzawa and others (e.g., Oniki et al., 1965; Johnson, 1971), in the framework of the two-country, two-good, two-factor global economy. The model has been extended and generalized to reveal dynamic interactions between economic growth and trade patterns (e.g., Jones et al., 1984; Ethier et al., 1986; Bhagwati, 1991; Wong, 1995; Vellutini; 2003). Although there are many analytical difficulties in studying two-country, dynamic-optimization models with wealth change, many studies are made to study the effects of saving, technology, and various policies on global growth and international trade within this framework (e.g. Frenkel et al., 1987; Jensen, 1994; Valdés, 1999; Nishimura et al., 2002; and Sorger, 2002). This study are different from these studies in describing household behaviour. Moreover, this study makes another contribution to the literature of endogenous global growth and endogenous knowledge by introducing international tourism. 
This study is to introduce tourism into a dynamic general equilibrium model with endogenous wealth and knowledge. Tourism has a special feature. Tourism converts some non-traded goods into tradable ones. In association with rapid economic globalization and global economic growth in different regions tourism has been increasingly expanded in national economies (Sinclair, 2002; Lee et al., 2008; Schubert et al., 2011; Seentanah, 2011; Sun, 2014). There is an increase in studies of tourism in economics (e.g., Sinclair et al., 1997; Hazari et al., 2004; and Hazari et al., 2011). As reviewed by Chao et al. (2009) most studies of development of tourism are static. As there are dynamic interdependent relations between economic growth, tourism and other economic activities (e.g. Corden et al., 1982; Copeland, 1991; Dwyer et al., 2004; Oh, 2005; Blake et al. 2006; Zeng et al., 2011), there is a need to build some analytical frameworks in which tourism has endogenous relations with other economic activities. This paper studies the issues of trade and tourism with endogenous capital and knowledge by synthesizing the two models by Zhang. Zhang (1992) built a multi-country model of wealth accumulation with endogenous knowledge utilization and creation. The model does not take account of international tourism. Zhang (2015) deals with tourism and global economic growth in a general equilibrium framework. This study applies the ideas in Zhang (1992) to the trade model with tourism. The rest of the paper is organized as follows. In section 2 we build the basic model. In section 3 we show how to solve the differential equations and simulate the dynamic movement of the international economy. In section 4 we conduct comparative dynamic analysis to study the effects of changes in some parameters on the motion of the global economy. In section 5 we conclude the study. We prove the main results of section 3 in the appendix.

\section{The Model}

We consider a global economy which consists of any number of national economies. Following Zhang (2015), we apply the Uzawa two-sector growth model to model national economies (Uzawa, 1961, 1963). Except endogenous knowledge (Zhang, 1992), almost all aspects of the model in this study are based on Zhang $(2012,2015)$. Production sectors employ capital and labor inputs. We assume that all markets are perfectly competitive. The outputs of production sectors are sold to households and other sectors. Households supply labor and assets to production sectors. Input factors are inelastically supplied and the available factors are fully utilized at every moment. Saving is only by households. This implies that all earnings of firms are distributed in the form of payments to factors of production. The modelling framework is neoclassical with Zhang's utility function. The neoclassical growth theory is based the pioneering works of Solow (1956). The Solow one-sector model with homogenous population has been extended and generalized by in different ways (e.g., Diamond, 1965; Stiglitz, 1967; Burmeister et al., 1970; Benhabib et al. 1994; Drugeon et al., 2001; Ortigueira et al., 2002). The two-sector model uses capital and labor as input factors. One sector produces industrial good and the other consumer good. In this study the capital good in this study is the same as the capital good in the Solow model. It can be used for consumption and investment. This differs from the Uzawa model in which the capital good can be used only for investment. We base the traditional neoclassical trade model to describe international trade (Oniki and Uzawa, 1965, see also, Brecher, et al., 2002; Sorger, 2002). Following lkeda et al. (1992), we assume that the international economy produces a homogenous tradable commodity. Each country supplies one (national) consumer good/service. Different from all the formal models In the traditional trade growth theory, Zhang (2015) introduces tourism into the trade growth theory. This 
study extends Zhang's tourism trade model by introducing knowledge as an endogenous variable.

The global economy has multiple countries, indexed by $j=1, \ldots, J$. Each country has a labor force, $N_{j},(j=1, \ldots, J)$, which are constant. The households in each country consume goods and services. Foreign tourists consume services, not traded good. Tourism converts the non-traded good into an exportable commodity. The assets of the economy are owned by households. The households' incomes are used to consume and save.

We use $K_{j}(t)$ and $\bar{K}_{j}(t)$ to represent respectively for the capital stocks employed and the wealth owned by country $j$. We use $K_{i j}(t)$ and $K_{s j}(t)$ to stand for the capital stocks employed by country $j$ 's capital good sector and service sector. There is no migration between countries. Labor is completely mobile within the country. We use $w_{j}(t)$ and $r_{j}(t)$, respectively, to stand for wage and interest rates in the $j$ th country. We neglect transaction costs. The interest rate is equal cross the world economy, i.e., $r(t)=r_{j}(t)$. Let subscripts, $i, s$, denote the industrial and services sectors, respectively. We use $(q, j)$ to represent sector $q$ in country $j$. Let $F_{q j}(t)$ represent the output levels of $(q, j)$ 's sector at time $t$.

\section{Behavior of producers}

Knowledge is supposed to be a public good which can be freely used by different producers. We assume that the sector employs two productive factors, capital, $K_{q j}(t)$, and labor, $N_{q j}(t)$, at each point in time $t$. As in Zhang (1992), we specify the production functions as

$$
F_{q j}(t)=A_{q j} Z^{m_{q j}}(t) K_{q j}^{\alpha_{q j}}(t) N_{q j}^{\beta_{q j}}(t), \alpha_{q j}, \beta_{q j}>0, \alpha_{q j}+\beta_{q j}=1, \quad j=1, \ldots, J, q=i, s, \text { (1) }
$$

in which $Z(t)(>0)$ is the knowledge stock at time $t, \alpha_{q j}$ and $\beta_{q j}$ are positive parameters. Here, we call $m_{q j}(q, j)$ 's knowledge utilization efficiency parameter. If we interpret $Z^{m_{q j}} \beta_{q j}(t) N_{j}(t)$ as $(q, j)$ 's qualified labor force, we see that the production function is a neoclassical one and homogeneous of degree one with inputs.

We use $p_{j}(t)$ to stand for country $j$ 's price of consumer goods. Markets are competitive, thus labor and capital earn their marginal products, and firms earn zero profits. The rate of interest and wage rates are determined by markets. The production sectors chooses the two variables, $K_{q j}(t)$ and $N_{q j}(t)$, to maximize the following profits

$$
\begin{aligned}
& F_{i j}(t)-\left(r(t)+\delta_{k j}\right) K_{i j}(t)-w_{j}(t) N_{i j}(t), \\
& p_{j}(t) F_{s j}(t)-\left(r(t)+\delta_{k j}\right) K_{s j}(t)-w_{j}(t) N_{s j}(t) .
\end{aligned}
$$


The marginal conditions are given by

$$
r(t)+\delta_{k j}=\frac{\alpha_{i j} F_{i j}(t)}{K_{i j}(t)}=\frac{\alpha_{s j} p_{j}(t) F_{s j}(t)}{K_{s j}(t)}, w_{j}(t)=\frac{\beta_{j i} F_{i j}(t)}{N_{i j}(t)}=\frac{\beta_{s j} p_{j}(t) F_{s j}(t)}{N_{s j}(t)},
$$

where $\delta_{k j}$ is the depreciation rate of physical capital in country $j$. Many studies show that many factors affect location choice of firms in different ways (e.g. Lee et al., 1996; Henisz, 2000; Busse et al., 2007; Almazan et. al., 2007; De Beule et al., 2012; Colombo et al., 2014). For simplicity of analysis this study uses the margional conditions (2) to determine behaviour of the sectors.

\section{Behavior of households}

Consumers choose consumption level of commodity, how much to travel, and how much to save. This study applies the approach to consumers' behavior proposed by Zhang in the early 1990s (Zhang, 1993, 2015). We use $\bar{k}_{j}(t)$ to represent the per capita wealth in country $j$. The representative household has the following current income

$$
y_{j}(t)=r(t) \bar{k}_{j}(t)+w_{j}(t) \text {. }
$$

The variable $y_{j}(t)$ is called the current income. We assume that selling and buying wealth can be conducted instantaneously without any transaction cost. The disposable income is

$\hat{y}_{j}(t)=y_{j}(t)+\bar{k}_{j}(t)$.

The disposable income is distributed between saving and consumption. The consumer has the total amount of income $\hat{y}_{j}$ to use for consumer goods, $c_{s j}(t)$, capital goods, $c_{i j}(t)$, tourist consumption in country $q, c_{j q}(t)$, and savings, $s_{j}(t)$.

The total cost for touring countries is

$$
\sum_{q, q \neq j}^{J}\left(t_{j q}+p_{q}(t) c_{j q}(t)\right) \bar{d}_{j q}(t)
$$

where $\bar{d}_{j q}(t)$, and $p_{q}(t) c_{j q}(t)$ are respectively, the visit times from country $j$ to country $q$, and consumption of country $q$ 's services by the tourist from country $j$.

The budget constraints are

$$
c_{i j}(t)+p_{j}(t) c_{s j}(t)+\sum_{q \neq j}^{J} p_{q}(t) d_{j q}(t)+s_{j}(t)=\hat{y}_{j}(t),
$$

where $d_{j q}(t)=c_{j q}(t) \bar{d}_{j q}(t)$, We take on the following form of utility functions

$$
U_{j}(t)=c_{i j}^{\xi_{0 j}}(t) c_{s j}^{\gamma_{0 j}}(t) s_{j}^{\lambda_{0 j}}(t) \prod_{q \neq j}^{J} d_{j q}^{\varepsilon_{0 j q}}(t), \quad \xi_{0 j}, \gamma_{0 j}, \lambda_{0 j}>0, \varepsilon_{0 j q} \geq 0 .
$$

in which $\xi_{0 j}, \gamma_{0 j}, \lambda_{0 j}$, and $\varepsilon_{0 j q}$ are the elasticity of utilities of country $j^{\prime}$ s representative household with regard to industrial goods, services, saving, and travels to country $q$. We call 
$\xi_{0 j}, \quad \gamma_{0 j}, \lambda_{0 j}$, and $\varepsilon_{0 j q}$, respectively, the propensities to consume industrial goods, to consume services, to hold wealth, and to travel to country $q$.

Maximizing $U_{j}$ subject to budget (5) yields

$$
\begin{array}{r}
c_{i j}(t)=\xi_{j} \hat{y}_{j}(t), p_{j}(t) c_{s j}(t)=\gamma_{j} \hat{y}_{j}(t), s_{j}(t)=\lambda_{j} \hat{y}_{j}(t), p_{q}(t) d_{j q}(t)=\varepsilon_{j q} \hat{y}_{j}(t), \\
q \neq j, j, q=1, \ldots . J,
\end{array}
$$

where

$$
\xi_{j} \equiv \rho_{j} \xi_{0 j}, \gamma_{j} \equiv \rho_{j} \gamma_{0 j}, \quad \lambda_{j} \equiv \rho_{j} \lambda_{0 j}, \quad \varepsilon_{j q} \equiv \rho_{j} \varepsilon_{0 j q}, \quad \rho_{j} \equiv \frac{1}{\xi_{0 j}+\gamma_{0 j}+\lambda_{0 j}+\sum_{q \neq j}^{J} \varepsilon_{0 j q}} .
$$

These equations imply that there are positively proportional relations between the service consumption, consumption of the good and saving and the available income. We mention that in their study on tourism Schubert et al. (2009) apply the following isoelastic tourism demand function

$D_{T}(t)=a y_{f}^{\phi}(t) p^{-\varepsilon}(t)$,

where $y_{f}(t)$ is the disposable income of foreign countries, $\phi$ and $\varepsilon$ are respectively the income and price elasticities of tourism demand. Our model is similar to the case of $\phi=1$ and $\varepsilon=1$.

\section{The wealth dynamics}

According to the definition of $s_{j}(t)$, the wealth changes as follows

$\dot{\bar{k}}_{j}(t)=s_{j}(t)-\bar{k}_{j}(t)$.

The change in the wealth equals the saving minus the dissaving.

\section{Full employment of capital and labor}

The total capital stocks utilized by country $j, K_{j}(t)$, is used for the two sectors. We have full employment of labor and capital as follows

$$
K_{i j}(t)+K_{s j}(t)=K_{j}(t), \quad N_{i j}(t)+N_{s j}(t)=N_{j}, j=1, \ldots, J \text {. }
$$

\section{Balance conditions for global wealth}

The total capital stock employed by the production sectors equals the total wealth owned by all the countries

$$
\sum_{j=1}^{J} K_{j}(t)=\sum_{j=1}^{J} \bar{k}_{j}(t) N_{j}
$$


Equilibrium conditions for national consumer goods

For each country, the demand for services is equal to the supply of services

$N_{j} c_{s j}(t)+\sum_{q \neq j}^{J} d_{q j}(t) N_{q}=F_{s j}(t)$.

\section{Knowledge creation}

Following Zhang (1992), we use knowledge as an international public good. We assume that knowledge growth is through Arrow's learning by doing (Arrow, 1962). We suggest the equation for knowledge growth as follows

$$
\dot{Z}(t)=\sum_{j=1}^{J}\left(\frac{\tau_{i j} F_{i j}(t)}{Z^{\varepsilon_{i j}}(t)}+\frac{\tau_{s j} F_{s j}(t)}{Z^{\varepsilon_{s j}}(t)}\right)-\delta_{z} Z(t)
$$

in which $\delta_{z}(\geq 0)$ stands for the depreciation rate of knowledge, and $\varepsilon_{q j}$ and $\tau_{q j}$ are parameters. The parameters $\tau_{q j}$ are non-negative. The term $\tau_{i j} F(t) / Z^{\varepsilon_{i j}}(t)$ implies the contribution to knowledge accumulation through learning by doing by country $j^{\prime} s$ capital good sector. To explain this term, consider that knowledge has the following relation with country $j$ 's total industrial output during some period

$$
Z(t)=a_{1}\left\{\int_{0}^{t} F_{j}(\theta) d \theta\right\}^{a_{2}}+a_{3}
$$

in which $a_{1}, a_{2}$ and $a_{3}$ are positive parameters. The knowledge accumulation through learning by doing exhibits decreasing (increasing) returns to scale in the case of $a_{2}<(>) 1$. Take the derivatives of the equation

$\dot{Z}(t)=\frac{\tau_{i j} F_{j}(t)}{Z^{\varepsilon_{i j}}(t)}$

where $\tau_{i j} \equiv a_{1} a_{2}$ and $\varepsilon_{i j} \equiv 1-a_{2}$.

We thus built the dynamic growth model. The model includes distributions of income and wealth, consumption and labor distribution, international patterns of tourism, and capital and knowledge accumulation as endogenous variables. The rest of the paper examines dynamic behavior of the system.

\section{The Dynamics and Equilibrium}

The global economy has any number of national economies countries. Both wealth and knowledge change over time. We have nonlinear and differential equations to describe the motion of wealth and knowledge. It is almost impossible to analytically solve such nonlinear differential equations. This study relies on computer simulation to plot the motion of the dynamic system. First we provide a computational procedure to plot the motion of the global economy. Before showing the result, we have a new variable $z_{1}(t)$

$z_{1}(t) \equiv \frac{r(t)+\delta_{k 1}}{w_{1}(t)}$. 
Lemma

The motion of the economic system is determined by $J+1$ differential equations with $z_{1}(t),\left\{\bar{k}_{j}(t)\right\}$, and $Z(t)$, where $\left\{\bar{k}_{j}(t)\right\} \equiv\left(\bar{k}_{2}(t), \cdots, \bar{k}_{J}(t)\right)$ and as the variables

$\dot{z}_{1}(t)=\Phi_{1}\left(z_{1}(t),\left\{\bar{k}_{j}(t)\right\}, Z(t)\right)$,

$\dot{\bar{k}}_{j}(t)=\Phi_{j}\left(z_{1}(t),\left\{\bar{k}_{j}(t)\right\}, Z(t)\right), \quad j=2, \ldots, J$,

$\dot{Z}(t)=\Lambda\left(z_{1}(t),\left\{\bar{k}_{j}(t)\right\}, Z(t)\right)$,

in which $\Phi_{j}(t)$ and $\Lambda(t)$ are unique functions of $z_{1}(t),\left\{\bar{k}_{j}(t)\right\}$, and $Z(t)$, defined in the appendix. At any point in time the other variables are unique functions of $z_{1}(t),\left\{\bar{k}_{j}(t)\right\}$, and $Z(t)$ by the following procedure: $r(t)$ by (A2) $\rightarrow w_{j}(t)$ by (A4) $\rightarrow p_{j}(t)$ by (A5) $\rightarrow$ $\bar{k}_{1}(t)$ by (A15) $\rightarrow \hat{y}_{j}(t)$ by (A8) $\rightarrow c_{i j}(t), c_{s j}(t), d_{j q}(t)$ and $s_{j}(t)$ by (7) $\rightarrow N_{s j}(t)$ by (A9) $\rightarrow N_{i j}(t)$ by $(\mathrm{A} 10) \rightarrow K_{s j}(t)$ and $K_{i j}(t)$ by $(\mathrm{Al}) \rightarrow K_{j}(t)$ by $(9) \rightarrow F_{i j}(t)$ and $F_{s j}(t)$ by the definitions $\rightarrow K(t)=\sum_{j=1}^{J} K_{j}(t)$.

The lemma enables us to plot the motion of the economic system with any number of national economies. It should be remarked that we don't provide the explicit functional forms of (13) as the expressions are tedious. We simulate the model by specifying the parameter values as follows

$N_{1}=10, N_{2}=20, N_{3}=60, A_{i 1}=1.2, A_{i 2}=1, A_{i 3}=0.8, A_{s 1}=1.1, A_{s 2}=0.9, A_{s 3}=0.7$,

$m_{i 1}=0.4, m_{i 2}=0.2, m_{i 3}=0.1, m_{s 1}=0.4, m_{s 2}=0.2, m_{s 3}=0.1, \delta_{z}=0.06, \tau_{i 1}=0.02$,

$\varepsilon_{i 1}=0.01, \tau_{i 2}=0.01, \varepsilon_{i 2}=0.4, \tau_{i 3}=0.01, \varepsilon_{i 3}=0.04, \alpha_{i 1}=0.31, \alpha_{i 2}=0.33, \alpha_{i 3}=0.32$,

$\alpha_{s 2}=0.32, \alpha_{s 3}=0.36, \delta_{k 1}=0.05, \alpha_{s 1}=0.33, \delta_{k 2}=0.04, \delta_{k 3}=0.045, \lambda_{01}=0.7, \gamma_{01}=0.15$,

$\xi_{01}=0.1, \varepsilon_{012}=0.002, \varepsilon_{012}=0.007, \lambda_{02}=0.65, \gamma_{02}=0.07, \quad \xi_{02}=0.12, \varepsilon_{021}=0.004$,

$\varepsilon_{023}=0.008, \lambda_{03}=0.6, \gamma_{03}=0.08, \xi_{03}=0.15, \varepsilon_{031}=0.004, \varepsilon_{032}=0.008$.

Country 1,2 and 3 's populations are respectively 10,20 and 60 . Country 3 has the largest population. Country 1's total productivities of the two sectors, $A_{i 1}$ and $A_{s 1}$, are highest, country 2's second and Country 3 's lowest. Country 1 utilizes knowledge mostly effectively; country 2 next and country 3 utilizes knowledge lest effectively. We assume that the capital good sectors make contribution to knowledge with decreasing returns to scale. We neglect possible contributions to knowledge growth by the service sectors. The values of the parameters, $\alpha_{j}$, in the Cobb-Douglas productions are specified near 0.3 . Country 1 's propensity to save is 0.7 , country 2 's propensity to save is 0.65 , and country 3 's propensity to save is 0.6 . We specify the depreciation rates of physical capital near 0.05 . Countries vary in their propensities to consume tourism between countries. Many empirical studies on income elasticity of tourism demand (Syriopoulos, 1995; Lanza et al., 2003), and price elasticities (Garin-Mũnos, 2007). We have the following initial conditions

$z_{1}(0)=0.0065, \bar{k}_{2}(0)=15, \bar{k}_{3}(0)=4.5, \quad Z(0)=49$. 
The motion of the system is given in Figure 1. In Figure 1 each country's total product and the global product are defined as follows

$$
Y_{j}(t)=F_{i j}(t)+p_{j}(t) F_{s j}(t), \quad Y(t)=\sum_{j=1}^{J} Y_{j}(t) .
$$

The global product falls and rises. The knowledge rises and the global wealth falls. The three countries' total products and capital stocks employed by the three countries also fall. The other variables are plotted in Figure 1.

Figure 1

The Motion of the Global Economy
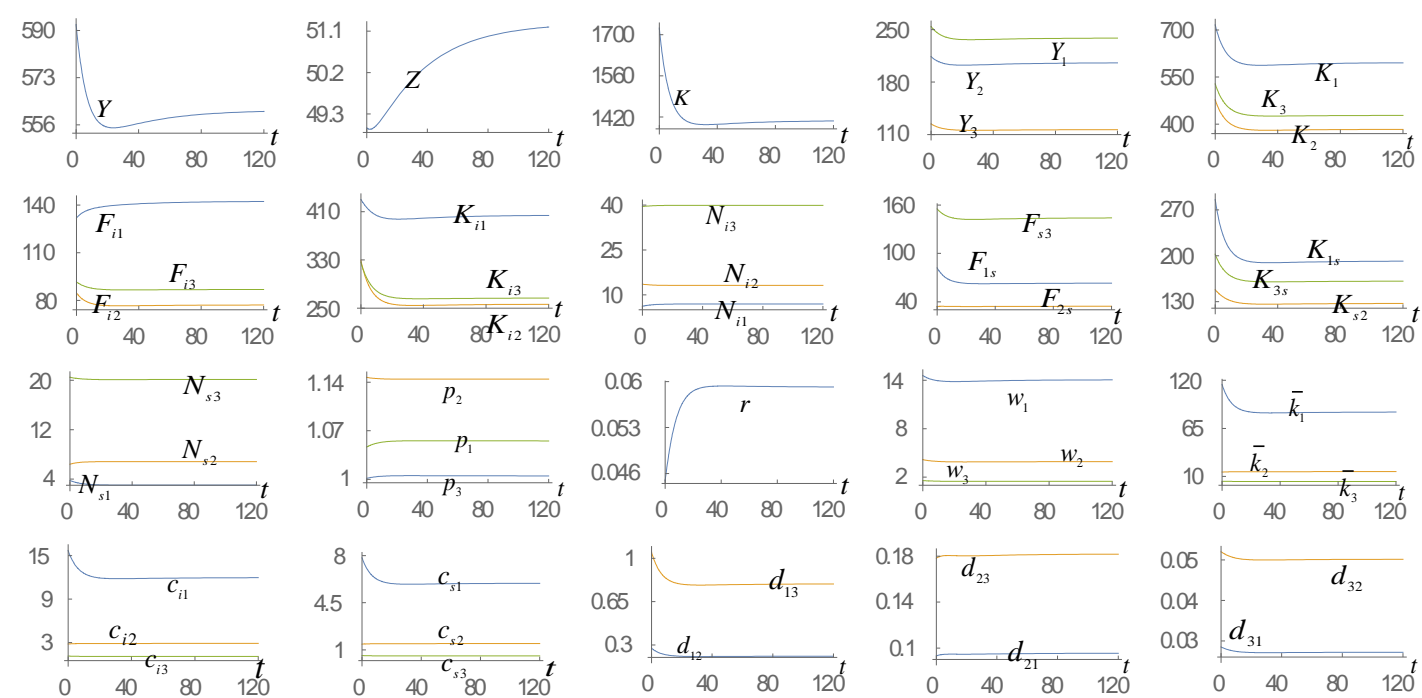

Source: Author's work

From Figure 1 we observe that all the variables become stationary in the long term. The simulation results hint on the existence of a stable equilibrium point. Following the lemma under (14), we calculate the equilibrium values of the variables as follows

$Y=561.3, \quad K=1408.3, Z=51.1, \quad r=0.059, \quad Y_{1}=205.9, \quad Y_{2}=116.5$,

$Y_{3}=238.9, \quad K_{1}=596.3, \quad K_{2}=383.9, \quad K_{3}=428.1, \quad F_{i 1}=142.4, \quad F_{i 2}=77.1$,

$F_{i 3}=86.8, \quad K_{i 1}=40.3, K_{i 2}=256.6, \quad K_{i 3}=266.8, \quad N_{i 1}=6.98, \quad N_{i 2}=13.2$,

$N_{i 3}=39.85, \quad F_{s 1}=63.2, \quad F_{s 2}=34.5, \quad F_{s 3}=144.1, \quad K_{s 1}=191.98, \quad K_{s 2}=127.2$,

$K_{s 3}=161.3, N_{s 1}=3.02, \quad N_{s 2}=6.84, N_{s 3}=20.2, p_{1}=1.01, \quad p_{2}=1.14$,

$p_{3}=1.06, \quad w_{1}=14.08, \quad w_{2}=3.92, \quad w_{3}=1.48, \quad \bar{k}_{1}=83.81, \quad \bar{k}_{2}=15.6, \bar{k}_{3}=4.3$,

$c_{i 1}=11.97, c_{i 2}=2.88, c_{i 3}=1.08, c_{s 1}=5.96, c_{s 2}=1.47, c_{s 3}=0.54$,

$d_{12}=0.21, d_{13}=0.79, d_{21}=0.01, d_{23}=0.18, d_{31}=0.03, d_{32}=0.05$.

It is straightforward to calculate the values of the four eigenvalues as follows $\{-0.22,-0.18,-0.12,-0.02\}$.

The eigenvalues are real and negative. This implies the existence of a locally stable equilibrium point. This means that we can effectively conduct comparative dynamic analysis. We now study what will happen to the global economy when some parameters are changed. 


\section{Comparative Dynamic Analysis}

This section is studies effects of changes in some parameters. The lemma makes it easy to calibrate the motion of all the variables as it gives a computational procedure. It is straightforward to study effects of change in any parameter on transitory processes and stationary states of all the variables. We use variable $\bar{\Delta} x_{j}(t)$ to stand for the change rate of the variable, $x_{j}(t)$, in percentage due to changes in the parameter value.

\section{An improvement in country l's knowledge utilization efficiency in the capital good sector}

We first examine what happens to the motion of the global economy if country 1's knowledge utilization efficiency in the capital good sector is improved as follows: $m_{1}: 0.4 \Rightarrow 0.41$. The simulation results are plotted in Figure 2 .

Figure 2

An Improvement in Country l's Knowledge Utilization Efficiency
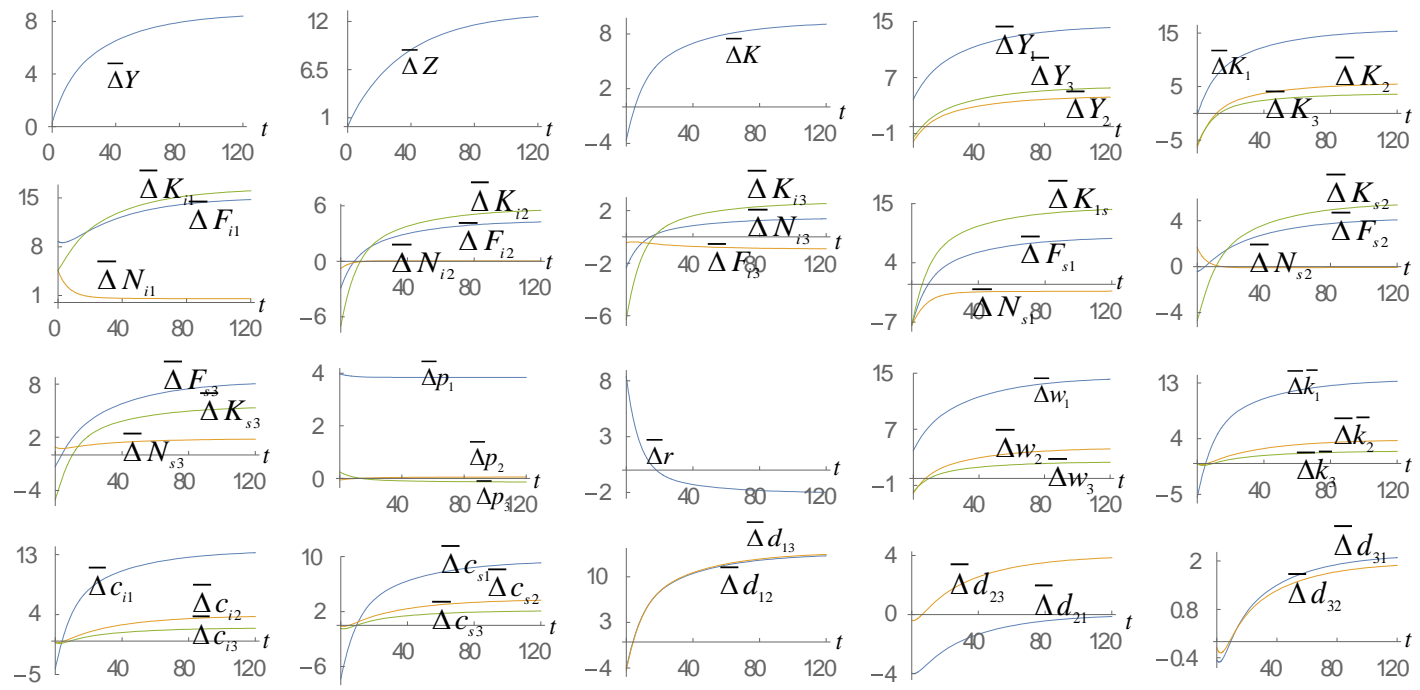

Source: Author's work

As sector $(i, 1)$ uses knowledge more effectively, the sector's output is improved and country 1's wage rate is improved. Sector $(i, 1)$ employs more labor and more capital stock. Sector $(s, 1)$ employs less labor. The output level and capital of sector $(s, 1)$ are lowered initially and are enhanced in the long term. The labor distribution in country 2 is slightly affected. Some of labor is shifted from the capital good sector to the service sector in country 3. The output levels and capital inputs of the two sectors are all enhanced in the long term in countries 2 and 3 . The global product, knowledge stock and wealth are all augmented. Country 1 produces more and uses more capital stocks. Country 2 (3) produces less and uses less capital stocks initially and produces more and uses more capital stocks in the long term. In the long term all countries' total products are increased. The price of service in country 1 is increased and the prices of services in countries 2 and 3 are slightly affected. The rate of interest rises initially and falls in the long term. The representative household in country 1 initially has less wealth, consumes less goods and services, travels less to the other two countries; in the long term the 
household has more wealth, consumes more goods and services, travels more to the other two countries. The representative household in country 2 (3) has more wealth and consumes more goods and services. The household in country 2 travels more to country 3 and less to country 1 . The household in country 3 travels less to the other two countries initially and in the long term travels more to the other two countries.

\section{The household in country 1 increasing the propensities to travel}

We now study what will happen to the global and national economies when country 1 's household increase the propensities to travel to country 2 and 3 as follows: $\varepsilon_{012}: 0.002 \Rightarrow 0.003$ and $\varepsilon_{012}: 0.007 \Rightarrow 0.008$. The simulation results are plotted in Figure 3.

As country l's household augments the propensities to tour the other two countries, the households of country 1 travel more to the other two countries. Sectors $(s, 2)$ and $(s, 3)$ enhance their outputs and employ more labor and capital stocks. Sectors $(i, 2)$ and $(i, 3)$ lower their outputs and employ less labor and capital stocks. It should be noted that as we omit possible contributions to knowledge growth from the service sectors, the knowledge stock does not rise as the output levels of the service sectors are enhanced. The knowledge stock is slightly affected. The global product rises initially and falls slightly in the long term. The global capital and capital stocks employed by the three economies are all reduced. Country 3's national product is increased and the other two countries' national products are reduced. The rate of interest is enhanced in association with falling capital stocks. The wage rates are reduced and prices of services are slightly affected. Sector $(s, 1)$ reduces the output and employs less labor and capital stocks. Sector $(i, 1)$ increases the output, and employs more labor and more capital stocks. All the households have less wealth and consume less goods and services. The households from countries 2 and 3 travel less to any other country.

Figure 3

Country 1's Household in Increasing the Propensities to Travel
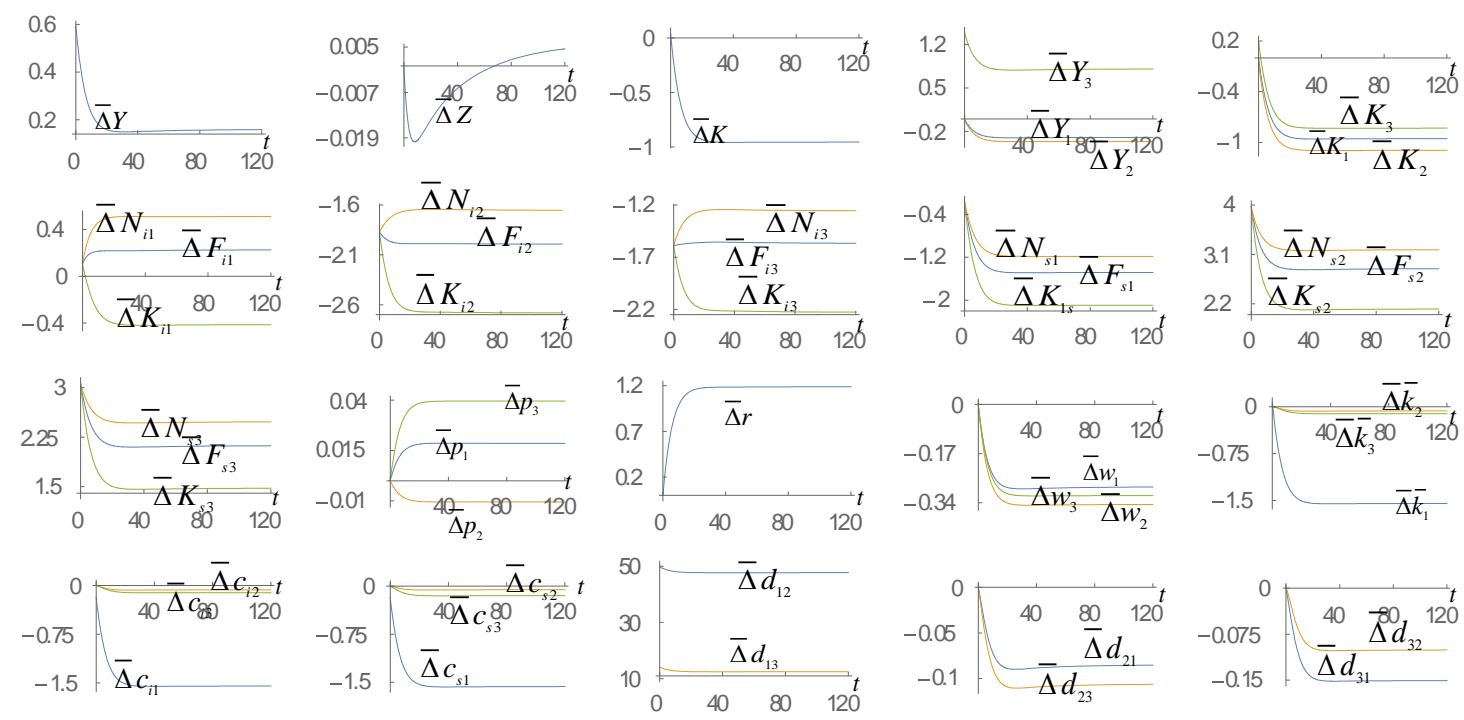

Source: Author's work 
An improvement in country l's learning by doing efficiency

We now study what will happen to the global and national economies when country I's learning by doing efficiency is improved as follows: $\tau_{i 1}: 0.02 \Rightarrow 0.022$. The simulation results are plotted in Figure 4. Comparing Figures 2 and 4 , we see that the effects are similar. As sector $(i, 1)$ makes more effectively to knowledge growth via learning by doing, the knowledge stock is augmented. The global product and global wealth are increased. Each country has more total product and uses more capital stocks. The output levels of all the sectors are enhanced. Each household has more wealth, consumes more goods and services, and travels more to the other countries.

Figure 4

An Improvement in Country l's Learning by Doing Efficiency
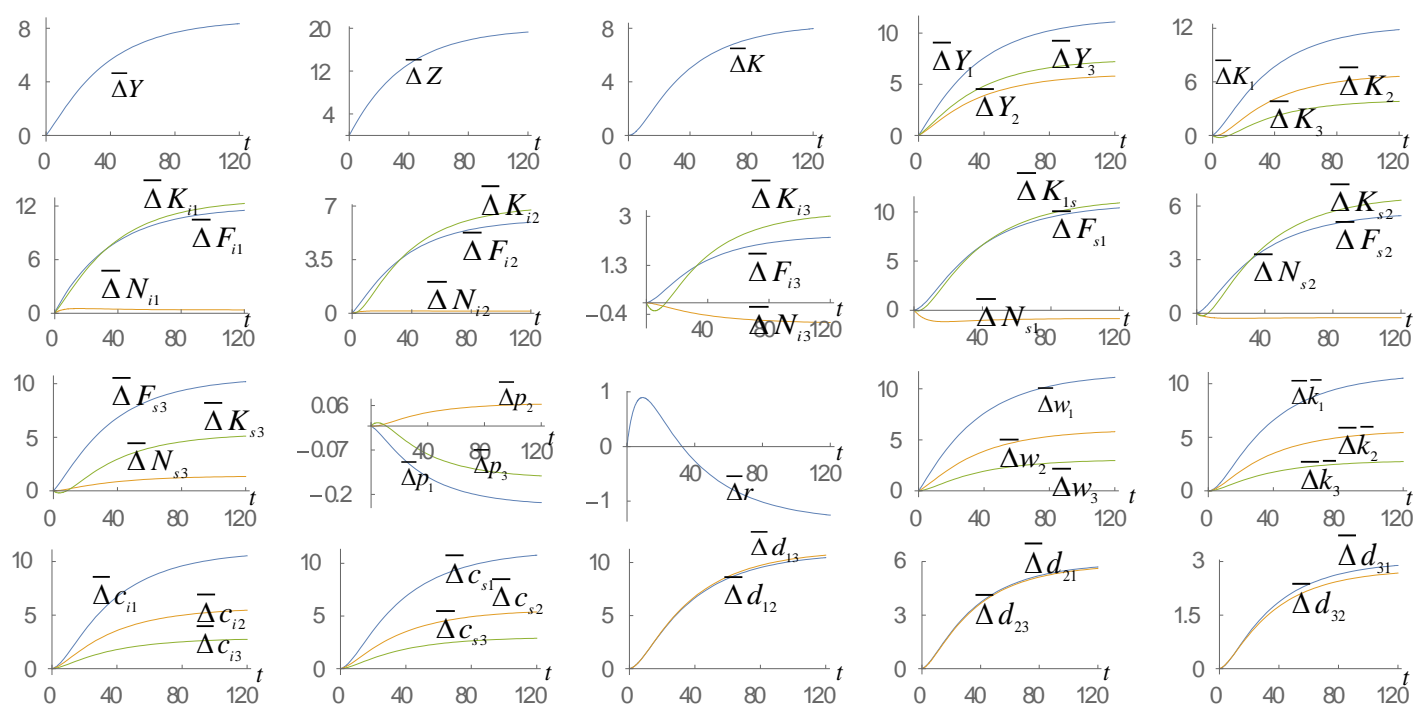

Source: Author's work

\section{Country 3's return to scale being enhanced}

We now study what will happen to the global and national economies when country 3's return to scale is enhanced as follows: $\varepsilon_{i 3}: 0.4 \Rightarrow 0.3$.

The simulation results are plotted in Figure 5. The wage rates in all the countries are increased. The rate of interest rises initially and falls in the long term. The price of service in country 2 rises and the prices of services in the other two countries fall. The knowledge stock is augmented. The global product and global wealth are increased. Each country has more total product and uses more capital stocks. The output levels of all the sectors are enhanced. Each household has more wealth, consumes more goods and services, and travels more to the other countries. 
Figure 5

Country 3's Return to Scale Being Enhanced
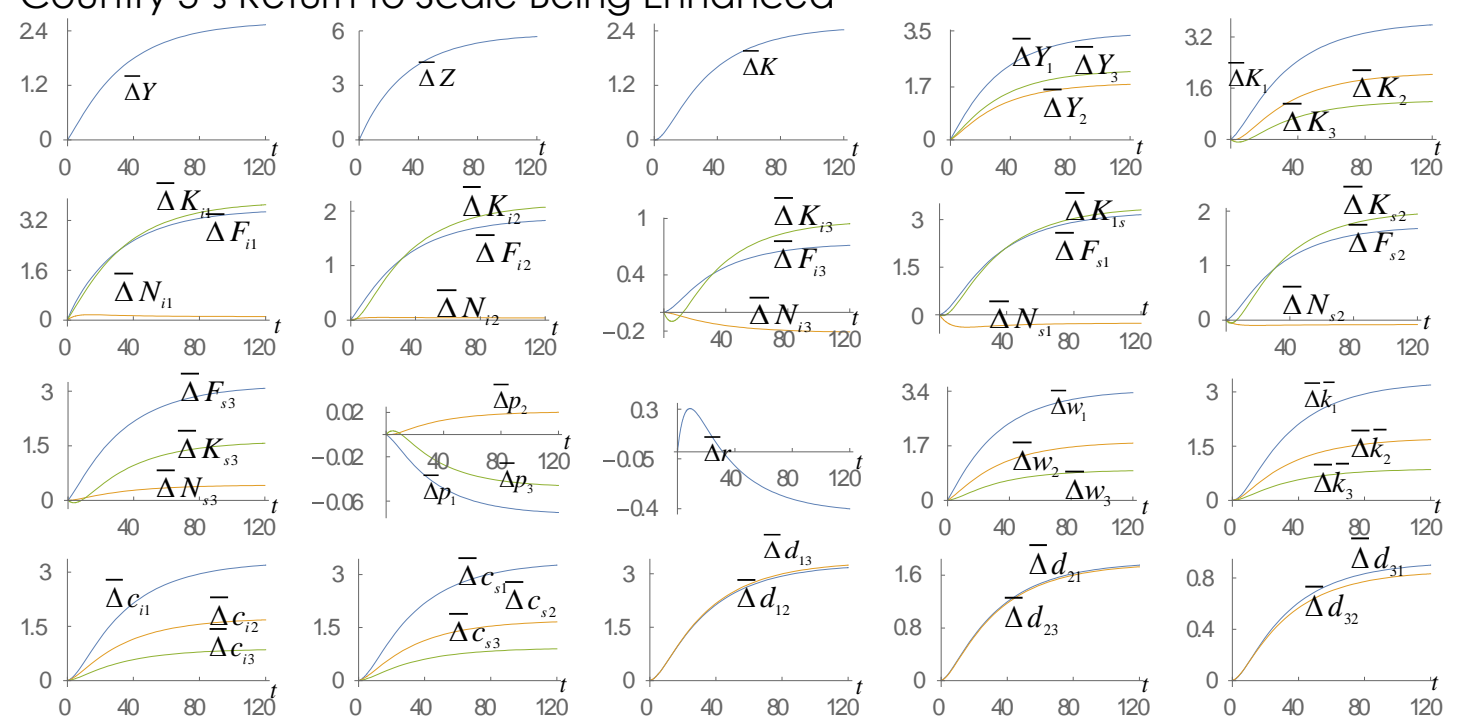

Source: Author's work

\section{Country 3's population being increased}

We now study how the motion of the global economy is affected when if country 3's population is increased as follows: $N_{3}: 60 \Rightarrow 65$. The simulation results are plotted in Figure 6.

Figure 6

Country 3's Population Being Increased
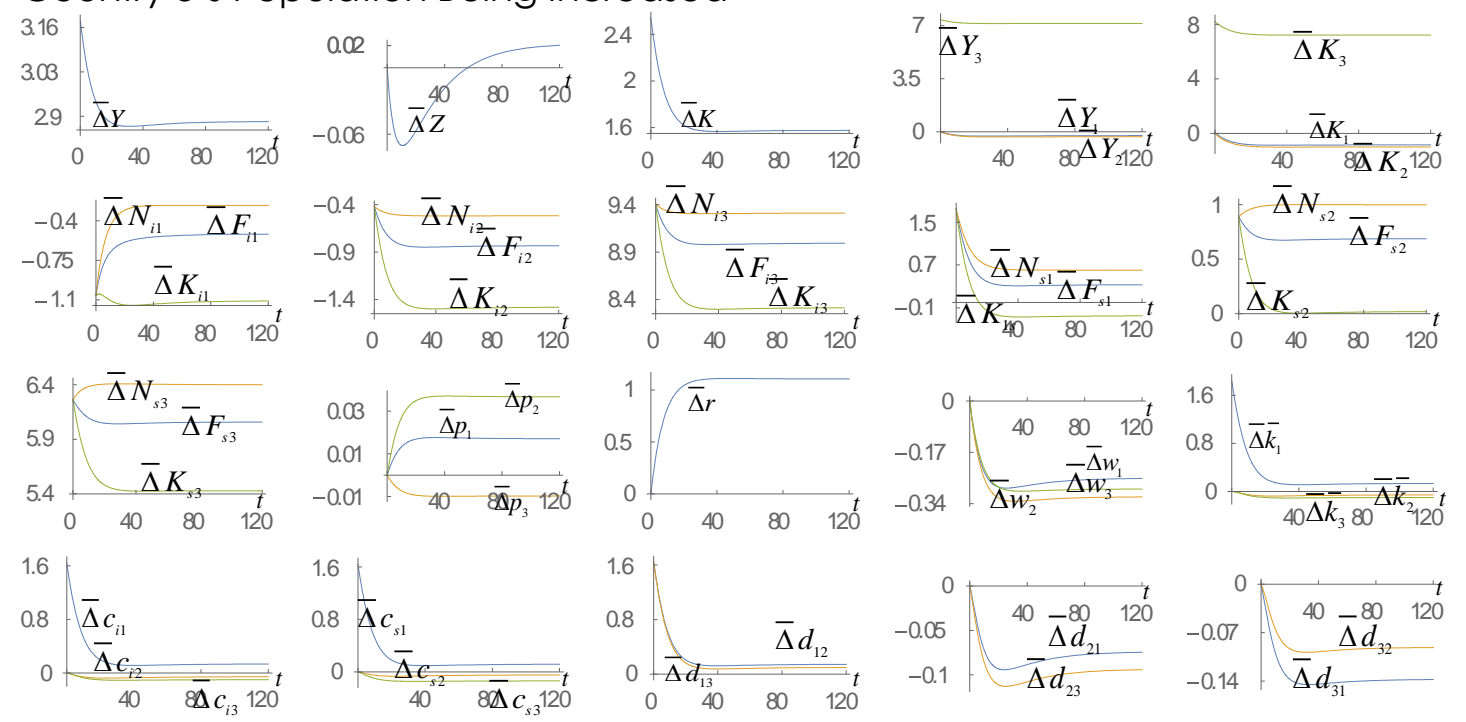

Source: Author's work

The knowledge stock is slightly affected. The global product and wealth are enhanced. Country 3's total product and capital stocks are increased, and the other two countries' total products and capital stocks are reduced. Country 3 increases the output level and employs more the input factors, and the other two countries reduce the output levels and employ less the input factors. The countries' output levels and 
labor force of the service sectors are increased. The rate of interest rises in tandem with falling in the wage rates. The prices of the services are slightly affected. The household of country 3 (2) has less wealth, consumes less goods and services, and travels less to the other two countries. The household of country 1 has more wealth, consumes more goods and services, and travels more to the other two countries. We see that as country 3 increases its population, in macroeconomic level country 3 benefits and the other two countries lose; in microeconomic level the household in country 1 benefits, and the household in country 2 (3) loses.

\section{Country 1 's population being increased}

We now study how the motion of the global economy is affected when if country 1's population is increased as follows: $N_{1}: 10 \Rightarrow 11$. The simulation results are plotted in Figure 7. Comparing Figures 6 and 7, we see that different from the rise in country 3's population, as country l's population is increased, all the households in the global economy benefit. This occurs as country 1 has highest knowledge utilization efficiency and is most efficient in learning by doing.

Figure 7

Country 3's Population Being Increased
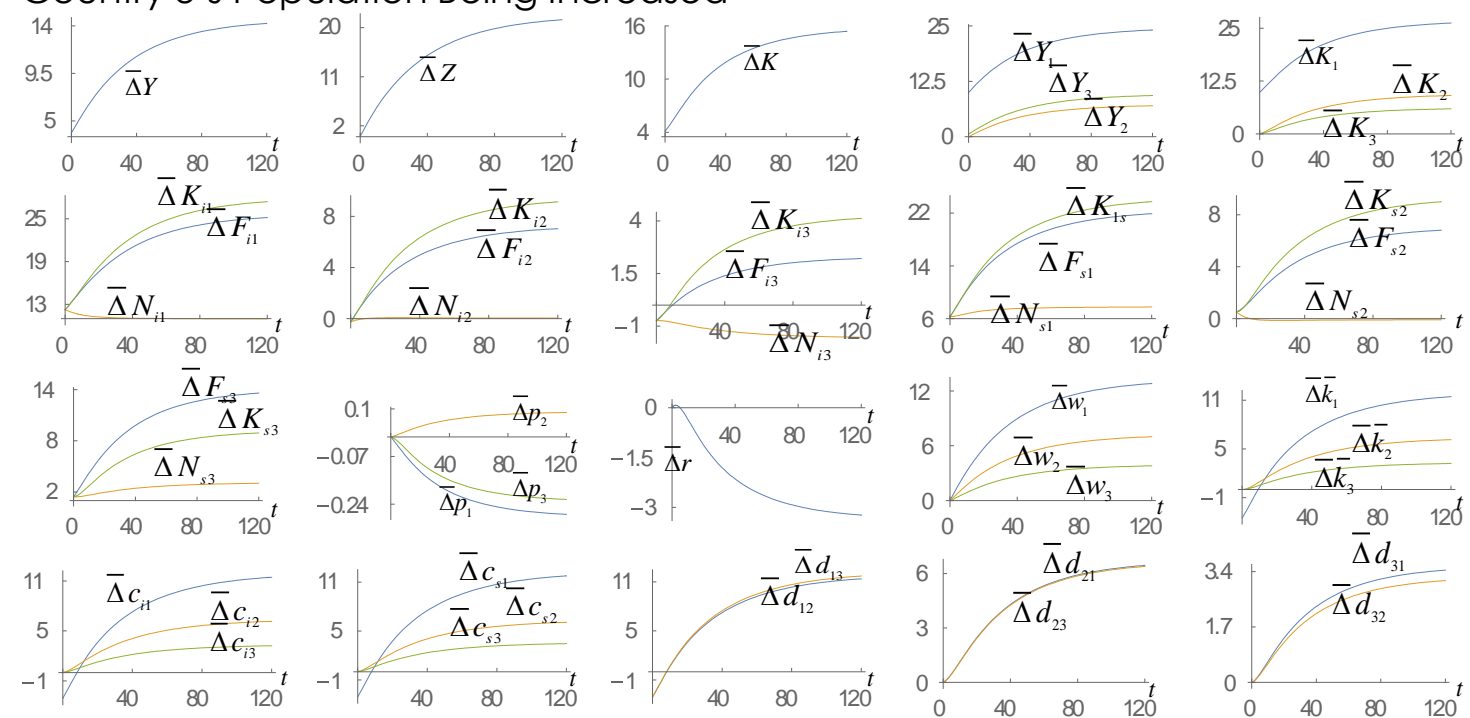

Source: Author's work

\section{A rise in country 1 's propensity to save}

We now deal with the effects of the following rise in country 1's propensity to save: $\lambda_{01}: 0.7 \Rightarrow 0.72$. The simulation results are plotted in Figure 8 . As country 1's propensity to save is increased, in the long term all the households benefit. In the global economy with endogenous knowledge, a rise in the country's propensity will not only increase other countries' consumption levels but also the country's consumption levels in the long term. 
Figure 8

A Rise in Country l's Propensity to Save
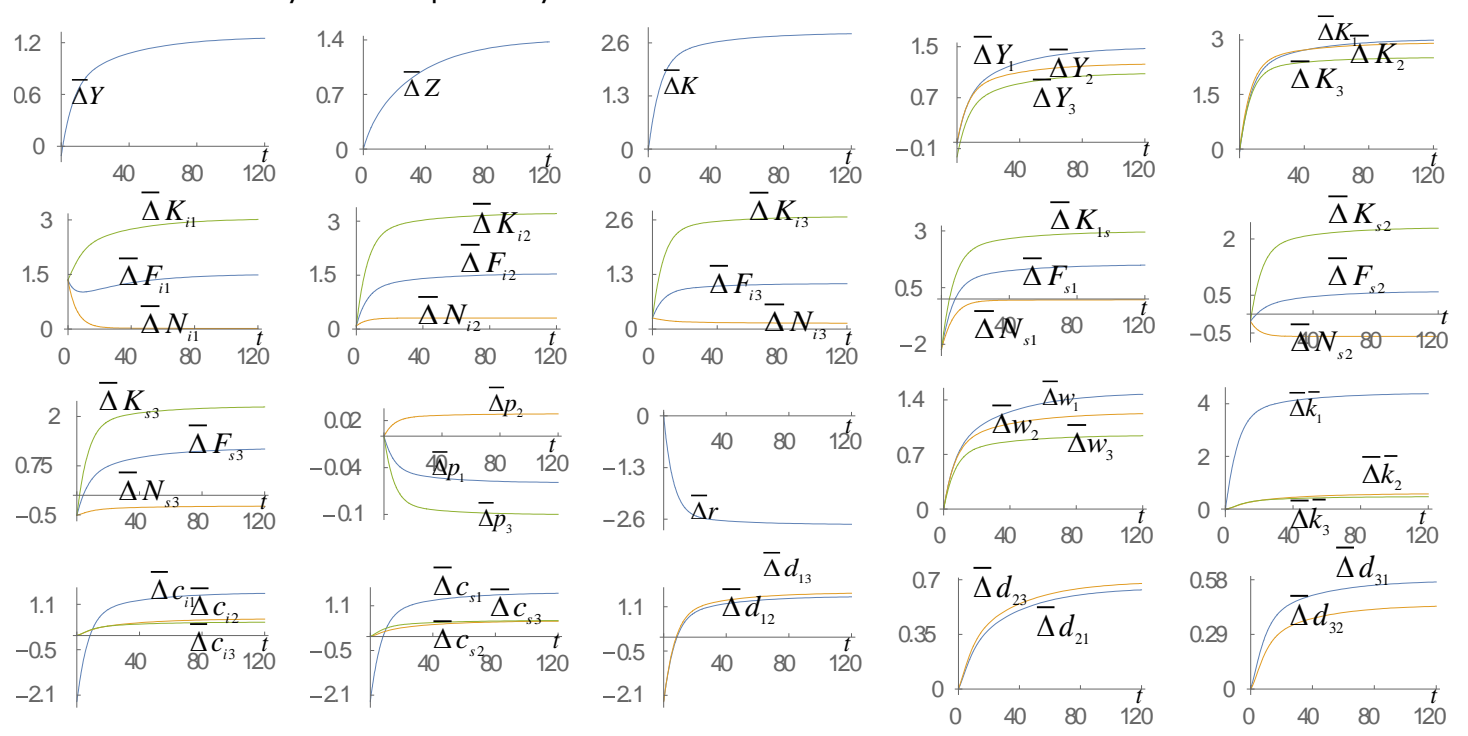

Source: Author's work

\section{Concluding Remarks}

This study introduced endogenous knowledge into a multi-country growth model with trade and tourism proposed by Zhang. We modelled a dynamic interaction among economic growth, structural change, knowledge accumulation, international trade and tourist flows. The model was built on the basis of Arrow's learning by doing, the Solow growth model, the Uzawa two-sector model, and the Oniki-Uzawa trade model. Capital accumulation is through saving, while knowledge is through learning by doing. The model is unique in this type of neoclassical growth trade models in that it introduces endogenous tourism the general equilibrium trade model with endogenous wealth and knowledge. We first built the multi-growth growth model with endogenous knowledge and tourism. Then we demonstrated that the motion of the $J$-country world economy can be described by $J+1$ differential equations. We also simulated the global economy with three countries, showing that the world dynamics has a unique equilibrium. We carried out comparative dynamic analysis with regard to one country's knowledge utilization efficiency, the efficiency of learning by doing, the propensity to save, the propensity to tour other countries, and the population. The analyses provide some insights into interdependence between growth, trade, tourism, wealth accumulation, and knowledge growth. For instance, the simulation shows that when a country's the propensities to travel to the other two countries are enhanced, the households of the country travel more to the other two countries; the three countries' economic structures are changed; the global product falls in the long term; the global capital and capital stocks employed by the three economies are all reduced and the rate of interest rises; different national products are affected differently; the wage rates are reduced and prices of services are slightly affected; all the households have less wealth and consume less goods and services. The households from the other two countries travel less to any other country. Our model can be extended and generalized in different directions. For instance, it is significant to examine behavior of the dynamic system when the utility functions or/and production functions are taken on other forms. The Solow model and Uzawa two-sector growth 
models are the two key models in the neoclassical economic growth theory and the Oniki-Uzawa growth model is a main key model of global economic dynamics with capital accumulation. These models have been generalized and extended in different ways. We only take account of learning by doing in knowledge accumulation. We may also introduce research and education into the model.

\section{References}

1. Agénor, P. R. (2004), "Does globalization hurt the poor?", International Economics and Economic Policy, Vol. 1 No 1, pp. 21-51.

2. Aghion, P., Blundell, R., Griffith, R., Howitt, P., Prantl, S. (2009), "The effects of entry on incumbent innovation and productivity", The Review of Economics and Statistics, Vol. 91 No. 1, pp. 20-32.

3. Aghion, P., Howitt, P. (1992), "A model of growth through creative destruction", Econometrica, Vol. 60 No. 2, pp. 323-351.

4. Almazan, A., DeMotta, A., Titman, S. (2007), „Firm location and the creation and utilization of human capital", Review of Economic Studies, Vol. 74 No. 4, pp. 13051327.

5. Arrow, K. J. (1962), "The economic implications of learning by doing", Review of Economic Studies, Vol. 29 No. 3, pp. 155-173.

6. Benhabib, J., Spiegel, M. (1994), "The role of human capital in economic development evidence from aggregate cross-country data", Journal of Monetary Economy, Vol. 34 No. 2, pp. 143-173.

7. Bhagwati, J. N. (1991). International Trade - Selected Readings, Mass., Cambridge, MIT Press.

8. Blake, A., Sinclair, M. T., Campos, J. A. (2006), „Tourism productivity- Evidence from the United Kingdom", Annals of Tourism Research, Vol. 33 No. 4, pp. 1099-1120.

9. Brecher, R. A., Chen, Z. Q., Choudhri, E. U. (2002), „Absolute and comparative advantage, reconsidered: The pattern of international trade with optimal saving", Review of International Economics, Vol. 10 No. 4, pp. 645-656.

10. Burmeister, E., Dobell, A. R. (1970). Mathematical Theories of Economic Growth, London, Collier Macmillan Publishers.

11. Busse, M., Hefeker, C. (2007), „Political risk, institutions and foreign direct investment", European Journal of Political Economy, Vol. 23 No. 2, pp. 397-415.

12. Chao, C. C., Hazari, B. R., Laffargue, Y. P., YU, E. S. H. (2009), „A dynamic model of tourism, employment, and welfare: The case of Hong Kong", Pacific Economic Review, Vol. 14 No. 2, pp. 232-245.

13. Chari, V. V., Hopenhayn, H. (1991), "Vintage human capital, growth, and the diffusion of new technology", The Journal of Political Economy, Vol. 99 No. 6, pp. $1142-1165$.

14. Colombo, L., Dawid, H. (2014), "Strategic Location choice under dynamic oligopolistic competition and spillovers", Journal of Economic Dynamics \& Control, Vol. 48, No. November, pp. 288-307.

15. Copeland, B. R. (1991), "Tourism, welfare and de-industrialization in a small open economy", Economica, Vol. 58 No. 232, pp. 515-529.

16. Corden, W. M., Neary, J. P. (1982), „Booming sector and de-industrialization in a small open economy", Economic Journal, Vol. 92 No. 368, pp. 825-848.

17. De Beule, F., Duanmu, J. L. (2012), "Locational determinants of internationalization: A firm-level analysis of Chinese and Indian acquisitions", European Management Journal, Vol. 30 No. 3, pp. 264-277. 
18. Diamond, P. A. (1965), "Disembodied technical change in a two-sector model", Review of Economic Studies, Vol. 32 No. 2, pp. 161-168.

19. Drugeon, J. P., Venditti, A. (2001), „Intersectoral external effects, multiplicities \& indeterminacies", Journal of Economic Dynamics \& Control, Vol. 25 No. 5, pp. 765787.

20. Dwyer, L., Forsyth, P., Spurr, R. (2004), „Evaluating Tourism's Economic Effects: New and old approaches", Tourism Management, Vol. 25 No. 3, pp. 307-317.

21. Ethier, W. J., Svensson, L. E. O. (1986), „The theorems of international trade with factor mobility", Journal of International Economics, Vol. 20 No. 1-2, pp. 21-42.

22. Frenkel, J. A., Razin, A. (1987). Fiscal Policy and the World Economy, Cambridge, MIT Press.

23. Gaŕin-Mũnos, T. (2007), "German demand for tourism in Spain", Tourism Management, Vol. 28 No. 1, pp. 12-22.

24. Gersbach, H., Schneider, M. T., Schneller, O. (2013), „Basic research, openness, and convergence", Journal of Economic Growth, Vol. 18 No. 1, pp. 33-68.

25. Grossman, G. M., Helpman, E. (1991). Innovation and Growth in the Global Economy, Cambridge, The MIT Press.

26. Hazari, B. R., Lin, J. J. (2011), "Tourism, terms of trade and welfare to the poor", Theoretical Economics Letters, Vol. 1 No. 1, pp. 28-32.

27. Hazari, B. R., Sgro, P. M. (2004), Tourism, Trade and National Welfare, Amsterdam, Elsevier.

28. Henisz, W. J. (2000), „The institutional environment for multinational investment", Journal of Law, Economics and Organization, Vol. 6 No. 2, pp. 334-364.

29. Hinloopen, J., Smrkolj, G., Wagener, F. (2013), „From mind to market: A global dynamic analysis of R\&D", Journal of Economic Dynamics \& Control, Vol. 37 No. 12, pp. 2729-2754.

30. Ikeda, S., Ono, Y. (1992), „Macroeconomic dynamics in a multi-country economy a dynamic optimization approach", International Economic Review, Vol. 33 No.3, pp. 629-644.

31. Jensen, B. S. (1994). The Dynamic Systems of Basic Economic Growth Models, Dordrecht, Kluwer Academic.

32. Johnson, H. G. (1971), "Trade and Growth: A Geometric Exposition", Journal of International Economics, Vol. 1 No. 1, pp. 83-101.

33. Jones, R. W., Kenen, P. B. (Eds.) (1984), Handbook of International Economics International Trade Amsterdam, North-Holland.

34. Lanza, A., Temple, P., Urga, G. (2003), „The implications of tourism specialisation in the long run: An econometric analysis for 13 OECD Economies", Tourism Management, Vol. 24 No. 3, pp. 315-321.

35. Lee, C. C., Chang, C. P. (2008), „Tourism development and economic growth: A closer look at panels", Tourism Management, Vol. 29 No. 1, pp. 180-192.

36. Lee, J. Y., Mansfield, E. (1996), "Intellectual property protection and US foreign direct investment", Review of Economics and Statistics, Vol. 78 No. 2, pp. 181-186.

37. Lucas, R.E. (1988), "On the mechanics of economic development", Journal of Monetary Economics, Vol. 22, No. 1, pp. 3-42.

38. Manasse, P., Turrini, A. (2001), "Trade, wages, and 'superstars'", Journal of International Economics, Vol. 54 No. 1, pp. 97-117.

39. Martin, P., Ottaviano, G. (2001), "Growth and agglomeration", International Economic Review, Vol. 42 No. 4, pp. 947-968. 
40. Nishimura, K., Shimomura, K. (2002), „Trade and Indeterminacy in a dynamic general equilibrium model", Journal of Economic Theory, Vol. 105 No. 1, pp. 244260.

41. Nocco, A. (2005), "The rise and fall of regional inequalities with technological differences and knowledge spillovers", Regional Science and Urban Economics, Vol. 35 No. 5, pp. 542-569.

42. Oh, C. O. (2005), "The contribution of tourism development to economic growth in the Korean economy", Tourism Management, Vol. 26 No. 1, pp. 39-44.

43. Oniki, H., Uzawa, H. (1965), „Patterns of trade and investment in a dynamic model of international trade", Review of Economic Studies, Vol. 32 No. 1, pp. 15-38.

44. Ortigueira, S., Santos, M. S. (2002), „Equilibrium dynamics in a two-sector model with taxes", Journal of Economic Theory, Vol. 105 No. 1, pp. 99-119.

45. Romer, P. M. (1986), "Increasing returns and long-run growth", Journal of Political Economy, Vol. 94 No 5, pp. 1002-1037.

46. Schubert, S. F., Brida, J. G. (2009), „A dynamic model of economic growth in a small tourism driven economy", Munich Personal RePEc Archive.

47. Schubert, S., Brida, J., Risso, A. (2011), "The impacts of international tourism demand on economic growth of small economies dependent on tourism", Tourism Management, Vol. 32 No. 2, pp. 377-385.

48. Seentanah, B. (2011), "Assessing the dynamic economic impact of tourism for island economies", Annals of Tourism Research, Vol. 38 No 1, pp. 291- 308.

49. Sinclair, M. (2002), "Tourism and economic development: A survey", The Journal of Development Studies, Vol. 34 No 5, pp. 1-51.

50. Sinclair, M. T., Stabler, M. (1997), The Economics of Tourism, London, Routledge.

51. Solow, R. (1956), "A contribution to the theory of growth", Quarterly Journal of Economics, Vol. $70 \mathrm{Nol}$, pp. 65-94.

52. Sorger, G. (2002), "On the multi-country version of the Solow-Swan model", The Japanese Economic Review, Vol. 54 No 2, pp. 146-164.

53. Stiglitz, J.E. (1967), „A two sector two class model of economic growth", Review of Economic Studies, Vol. 34 No. 2, pp. 227-238.

54. Sun, Y. (2014), „A framework to account for the tourism carbon footprint at island destinations", Tourism Management, Vol. 45 No. December, pp. 16-27.

55. Syriopoulos, T. C. (1995), "A dynamic model of demand for Mediterranean tourism", International Review of Applied Economics, Vol. 9 No. 3, pp. 318-336.

56. Uzawa, H. (1961), "On a two-sector model of economic growth", Review of Economic Studies, Vol. 29 No. 1, pp. 47-70.

57. Uzawa, H. (1963), "On a two-sector model of economic growth II", Review of Economic Studies, Vol. 30 No 2, pp. 105-118.

58. Uzawa, H. (1965), "Optimal technical change in an aggregative model of economic growth", International Economic Review, Vol. 6 Nol, pp. 18-31.

59. Valdés, B. (1999). Economic Growth - Theory, Empirics and Policy, Cheltenham, Edward Elgar.

60. Vellutini, C. (2003), "Capital mobility and underdevelopment traps", Journal of Development Economics, Vol. 71 No. 2, pp. 435-462.

61. Wong, K. Y. (1995). International Trade in Goods and Factor Mobility, Mass., Cambridge, MIT Press.

62. Zhang, W. B. (1992), "Trade and world economic growth - differences in knowledge utilization and creativity", Economic Letters, Vol. 39 No. 2, pp. 199206. 
63. Zhang, W. B. (1993), „Woman's labor participation and economic growth creativity, knowledge utilization and family preference", Economics Letters, Vol. 42 No. 1, pp. 105-110.

64. Zhang, W. B. (2012), „Tourism and economic structure in a small-open growth model", Journal of Environmental Management and Tourism, Vol. 3 No. 2, pp. 7692.

65. Zhang, W. B. (2015), „Tourism, trade and wealth accumulation with endogenous income and wealth distribution among countries", Ecoforum Journal of Economics, Vol. 4 No. 1, pp. 7-20.

66. Zeng, D. Z., Zhu, X. W. (2011), "Tourism and industrial agglomeration", The Japanese Economic Review, Vol. 62 No. 4, pp. 537-561.

\section{Appendix: Proving the Lemma}

We now derive dynamic equations for global economic growth. From (2), we have

$z_{j} \equiv \frac{r+\delta_{k}}{w_{j}}=\frac{a_{j} N_{i j}}{K_{i j}}=\frac{b_{j} N_{s j}}{K_{s j}}$,

where

$a_{j} \equiv \frac{\alpha_{i j}}{\beta_{i j}}, b_{j} \equiv \frac{\alpha_{s j}}{\beta_{s j}}$.

Insert $z_{j} / a_{j} \equiv N_{i j} / K_{i j}$ in $r+\delta_{k j}=\alpha_{i j} F_{i j} / K_{i j}$ from (2)

$r\left(z_{j}, Z\right)=\frac{\alpha_{i j} A_{i j} Z^{m_{i j}}}{a_{j}^{\beta_{i j}}} z_{j}^{\beta_{i j}}-\delta_{k j}, j=1, \ldots, J$.

From (A2) we get

$z_{j}\left(z_{1}, Z\right)=a_{j}\left(\frac{r+\delta_{k j}}{\alpha_{i j} A_{i j} Z^{m_{i j}}}\right)^{1 / \beta_{i j}}, j=2, \ldots, J$.

From (A1) and (A2), we have

$w_{j}\left(z_{1}, Z\right)=\frac{r+\delta_{k j}}{z_{j}}$.

From $z_{j}=b_{j} N_{s j} / K_{s j}$ and (1), we have

$p_{j}\left(z_{1}, Z\right)=\frac{b_{j}^{\beta_{s j}}\left(r+\delta_{k j}\right)}{\alpha_{s j} A_{s j} Z^{m_{s j}} z_{j}^{\beta_{s j}}}$.

From (11) and (7) we have

$\gamma_{j} \hat{y}_{j} N_{j}+\sum_{q \neq j}^{J} \varepsilon_{q j} \hat{y}_{q} N_{q}=p_{j} F_{s j}$.

Insert (1) in (A6)

$\gamma_{j} \hat{y}_{j} N_{j}+\sum_{q \neq j}^{J} \varepsilon_{q j} \hat{y}_{q} N_{q}=\frac{w_{j} N_{s j}}{\beta_{s j}}$.

By (3) we have

$\hat{y}_{j}\left(z_{1}, Z, \bar{k}_{j}\right)=(1+r) \bar{k}_{j}+w_{j}$.

Substituting (A8) into (A7) yields 


$$
N_{s j}\left(z_{1},\left(\bar{k}_{j}\right)\right)=\bar{R}_{j}+\left(\gamma_{j} N_{j} \bar{k}_{j}+\sum_{q \neq j}^{J} \varepsilon_{q j} N_{q} \bar{k}_{q}\right) R_{j},
$$

where

$$
R_{j}\left(z_{1}, Z\right) \equiv\left(\frac{1+r}{w_{j}}\right) \beta_{s j}, \bar{R}_{j}\left(z_{1}, Z\right) \equiv \beta_{s j} \gamma_{j} N_{j}+\frac{\beta_{j s}}{w_{j}} \sum_{q \neq j}^{J} w_{q} \varepsilon_{q j} N_{q} .
$$

From $N_{i j}+N_{s j}=N_{j}$ and (A9), we solve

$N_{i j}\left(z_{1}, Z,\left(\bar{k}_{j}\right)\right)=N_{j}-N_{s j}$.

With (A10) and (A11) we determine the labor distribution as functions of $z_{1}, Z$ and $\left(\bar{k}_{q}\right)$. From (A1) and (A10) we have

$$
K_{i j}\left(z_{1}, Z,\left(\bar{k}_{j}\right)\right)=\frac{a_{j} N_{i j}}{z_{j}}, K_{s j}\left(z_{1}, Z,\left(\bar{k}_{j}\right)\right)=\frac{b_{j} N_{s j}}{z_{j}} .
$$

From (9) and (10), we have

$$
\sum_{j=1}^{J}\left(K_{i j}+K_{s j}\right)=\sum_{j=1}^{J} \bar{k}_{j} N_{j} .
$$

Inserting (A12) in (A11) implies

$$
\sum_{j=1}^{J} \frac{a_{j} N_{j}}{z_{j}}+\sum_{j=1}^{J} \bar{z}_{j} N_{s j}=\sum_{j=1}^{J} \bar{k}_{j} N_{j}
$$

$$
\begin{aligned}
& \text { where } \\
& \bar{z}_{j} \equiv \frac{\left(b_{j}-a_{j}\right)}{z_{j}} .
\end{aligned}
$$

Insert (A9) in (A13)

$$
\gamma_{1} N_{1} \bar{z}_{1} R_{1} \bar{k}_{1}+\sum_{j=1}^{J}\left(\sum_{q \neq j}^{J} \varepsilon_{q j} N_{q} \bar{k}_{q}\right) \bar{z}_{j} R_{j}=R_{0}+\bar{k}_{1} N_{1} .
$$

where

$$
R_{0}\left(z_{1}, Z,\left\{\bar{k}_{j}\right\}\right)=\sum_{j=2}^{J} \bar{k}_{j} N_{j}-\sum_{j=1}^{J} \frac{a_{j} N_{j}}{z_{j}}-\sum_{j=1}^{J} \bar{z}_{j} \bar{R}_{j}-\sum_{j=2}^{J} \gamma_{j} N_{j} \bar{z}_{j} R_{j} \bar{k}_{j} .
$$

where $\left\{\bar{k}_{j}\right\} \equiv\left(\bar{k}_{2}, \ldots, \bar{k}_{J}\right)$. Solve (A14) with respect to $\bar{k}_{1}$

$$
\bar{k}_{1}=\Phi\left(z_{1}, Z,\left\{\bar{k}_{j}\right\}\right) \equiv
$$

$$
\left[R_{0}-\left(\sum_{q=2}^{J} \varepsilon_{q 1} N_{q} \bar{k}_{q}\right) \bar{z}_{1} R_{1}-\sum_{j=2}^{J}\left(\sum_{q \neq j, 1}^{J} \varepsilon_{q j} N_{q} \bar{k}_{q}\right) \bar{z}_{j} R_{j}\right]\left(\gamma_{1} \bar{z}_{1} R_{1}-1+\sum_{j=2}^{J} \varepsilon_{1 j} \bar{z}_{j} R_{j}\right)^{-1} \frac{1}{N_{1}} .
$$

Substitute $s_{j}=\lambda \hat{y}_{j}$ and $r \bar{k}_{j}+w_{j}$ into (8)

$$
\begin{aligned}
& \dot{\overline{k_{1}}}=\Phi_{0}\left(z_{1}, Z,\left\{\bar{k}_{j}\right\}\right) \equiv(1+r) \lambda_{1} \Phi+\lambda_{1} w_{1}-\Phi, \\
& \dot{\bar{k}}_{j}=\Phi_{j}\left(z_{1}, Z, \bar{k}_{j}\right) \equiv(1+r) \lambda_{j} \bar{k}_{j}+\lambda_{j} w_{j}-\bar{k}_{j}, j=2, \ldots, J, \\
& \dot{Z}=\Lambda\left(z_{1}, Z,\left\{\bar{k}_{j}\right\}\right) \equiv \sum_{j=1}^{J}\left(\frac{\tau_{i j} F_{i j}}{Z^{\varepsilon_{i j}}}+\frac{\tau_{s j} F_{s j}}{Z^{\varepsilon_{s j}}}\right)-\delta_{z} Z .
\end{aligned}
$$

Taking derivatives of equation (A15) with respect to $t$ yields 
$\dot{\overline{k_{1}}}=\frac{\partial \Phi}{\partial z_{1}} \dot{z}_{1}+\Lambda \frac{\partial \Phi}{\partial Z}+\sum_{j=2}^{J} \Phi_{j} \frac{\partial \Phi}{\partial \bar{k}_{j}}$,

where we use (A17). Insert (A18) in (A16)

$\dot{z}_{1}=\Phi_{1}\left(z_{1},\left\{\bar{k}_{j}\right\}\right) \equiv\left(\Phi_{0}-\Lambda \frac{\partial \Phi}{\partial Z}-\sum_{j=2}^{J} \Phi_{j} \frac{\partial \Phi}{\partial \bar{k}_{j}}\right)\left(\frac{\partial \Phi}{\partial z_{1}}\right)^{-1}$.

Following the procedure in the lemma we describe the dynamics of the economic system.

\section{About the author}

Wei-Bin Zhang, PhD (Umeå, Sweden), is Associate Dean of Graduate School of Management, Professor (since 2000 till now) in Ritsumeikan Asia Pacific University (APU), Japan. He graduated in 1982 from Department of Geography, Beijing University, China, and completed graduate study at Department of Civil Engineering, Kyoto University, Japan. After he completed his dissertation on economic growth theory under supervision of Prof. Ake E Andersson with Prof. Michio Morishima as the main examiner, he researched at the Swedish Institute for Futures Studies in Stockholm for 10 years. He also worked as visiting scholars in USA, Japan, Mainland China, Austria, Singapore and Hong Kong. His main research fields are nonlinear economic dynamics, growth theory, trade theory, East Asian economic development, and Confucianism. He has published about 200 academic articles (95 in peer review international journals), authorized 22 academic books in English by international publishing houses. Prof. Zhang is editorial board members of 7 peer-review international journals. Author can be contacted at wbz1@apu.ac.jp 